\title{
BLIND TEST SCREENING AND DETERMINATION OF BENZODIAZEPINE USING STRIP TEST AND TLC- SPECTROPHOTODENSITOMETRY
}

\author{
I Putu Purba Teguh Grantica ${ }^{1}$, Made Dewi Widyastuti ${ }^{1}$, \\ Anak Agung Gde Jaya Santika ${ }^{1}$, Ni Putu Ayu Kristiara Dewi ${ }^{1}$ \\ ${ }^{1}$ Program Studi Farmasi, Fakultas Matematika dan Ilmu Pengetahuan Alam, \\ Universitas Udayana \\ Email: purbateguh99@gmail.com
}

\begin{abstract}
ABSTRAK
Penelitian ini bertujuan untuk melakukan pengembangan metode analisis dengan mengkombinasikan teknik immunoassay (strip test) dengan KLT-Spektrofotodensitometri dalam melakukan skrining, konfirmasi, dan uji determinasi senyawa golongan benzodiazepine dalam sampel urin. Metode penelitian yang dilakukan secara eksperimental terhadap sampel urin yang belum diketahui senyawa yang terdapat dalam sampel tersebut, kemudian teknik immunoassay (strip test) digunakan sebagai uji pendahuluan untuk mengetahui golongan senyawa yang terdapat dalam sampel tersebut, kemudian dilanjutkan dengan preparasi sampel dengan teknik LLE (liquid liquid extraction) menggunakan pelarut organik etil asetat dan dapar fosfat $\mathrm{pH}$ 6. Kemudian dilakukan konfirmasi menggunakan metode KLT-Spektrofotodensitometri dengan menerapkan dua sistem fase gerak yaitu sistem TE (etil asetat: metanol: amonia (85: 10: $5 \% \mathrm{v} / \mathrm{v} / \mathrm{v})$ ) dan TA (Metanol : Amonia pekat (100 : $1,5 \% \mathrm{v} / \mathrm{v})$ ). Dilanjutkan dengan melakukan determinasi menggunakan metode KLTSpektrofotodensitometri dengan fase diam plat KLT silica gel $\mathrm{GF}_{254} \mathrm{~nm}$ dan fase gerak sistem TE. Berdasarkan hasil yang diperoleh yaitu dari uji skrining dengan teknik immunoassay, sampel urin positif mengandung senyawa golongan benzodiazepine, kemudian hasil dipertegas dengan uji konfirmasi, yang mana sampel urin memang benar positif mengandung senyawa golongan benzodiazepine dan terkonfirmasi senyawa flurazepam terdapat pada sampel tersebut. Selanjutnya, dilakukan uji determinasi untuk mengetahui secara spesifik kadar flurazepam yang terdapat dalam sampel, yang mana kadar yang diperoleh yakni $297,5480 \mu \mathrm{g} / \mathrm{mL}$ dan nilai ini berada di atas dosis letal karena di dalam sampel mengandung flurazepam dengan kadar $\geq 50-200 \mu \mathrm{g} / \mathrm{mL}$.
\end{abstract}

Kata kunci: Benzodiazepine, Uji Skrining, Uji Konfirmasi, Uji Determinasi, Immunoassay, KLTSpektrofotodensitometri

\begin{abstract}
The aims of this research is to develop an analytical method by combining the immunoassay technique (strip test) with TLC-Spectrophotodensitometry in screening, confirmation, and determination test of benzodiazepine compounds in urine samples. The research method was done with experimentally on unknown urine samples of compounds contained in the sample, then the immunoassay technique (strip test) was used as a preliminary test to determine the class of compounds contained in the sample, then proceed with sample preparation with the LLE (liquid-liquid extraction) using organic solvent ethyl acetate and phosphate buffer $\mathrm{pH}$ 6. Then the confirmation test is using the TLC-Spectrophotodensitometry method by applying two mobile phase systems namely TE (ethyl

1

I Putu Purba Teguh Grantica, Made Dewi Widyastuti, Anak Agung Gde Jaya Santika, Ni Putu Ayu Kristiara Dewi Program Studi Farmasi, Fakultas Matematika dan Ilmu Pengetahuan Alam, Universitas Udayana
\end{abstract}


acetate: methanol: ammonia (85: 10: 5\% v / v / v)) and TA (Methanol: concentrated ammonia (100: $1.5 \% \mathrm{v} / \mathrm{v})$ ). Followed by doing the determination test using the TLC-Spectrophotodensitometry method with the stationary phase is TLC silica gel GF254 nm and TE system for the mobile phase. Based on the results obtained from the screening test with immunoassay technique, urine samples positive contain benzodiazepine compounds, then the results are confirmed by a confirmation test, in which the urine sample is indeed positive containing benzodiazepine group compounds and confirmed flurazepam compounds are present in the sample. Next, the determination test was carried out to determine specifically flurazepam's concentration contained in the sample, where the concentration obtained was $297.5480 \mu \mathrm{g} / \mathrm{mL}$ and this value was above the lethal dose because in the sample contained flurazepam with levels $\geq 50-200 \mu \mathrm{g} / \mathrm{mL}$.

Keywords: Benzodiazepines, Screening Test, Confirmation Test, Determination Test, Immunoassay, TLC-Spectrophotodensitometry

\section{PENDAHULUAN}

Benzodiazepine merupakan obat golongan psikotropika yang memberikan efek sedasi dan pada umumnya diresepkan sebagai obat anti depresi, anestesi, dan antikonvulsan dengan mekanisme yaitu meningkatkan kerja dari neurotransmitter gamma aminobutyric acid (GABA-A) pada reseptor GABA [1]. Menurut UU RI No. 5 Tahun 1997 tentang Psikotropika, kelompok obat benzodiazepine termasuk ke dalam psikotropika golongan IV. Benzodiazepine adalah kelompok obat yang paling lazim untuk diresepkan dan sering ditemukan dalam kasus toksikologi, serta beberapa kasus penyalahgunaan. Diazepam (valium), bromazepam (lexotan), klordiazepoksid (librium), dan nitrazepam (mogadon) merupakan jenis golongan benzodiazepin yang paling banyak disalahgunakan [2].

Pada beberapa kasus forensik, obat golongan benzodiazepine yang 2 bekerja sebagai obat penenang sering disalahgunakan, sehingga diperlukan pengawasan yang ketat terkait penyalahgunaan obat-obatan golongan benzodiazepine tersebut. Identifikasi kasus-kasus forensik terkait penyalahgunaan obat ini, memerlukan metode yang sensitif dan efektif untuk mendeteksi dan mengidentifikasi keberadaan senyawa ini dalam matriks biologis.

Matriks biologi yang umumnya digunakan dalam pemeriksaan psikotropika yaitu urin. Urin merupakan salah satu spesimen pilihan karena keberadaan obat dan metabolitnya di urin relatif tinggi. Selain itu, sampel urin merupakan sampel yang paling mudah dan stabil untuk pemeriksaan. Dalam melakukan pemeriksaan benzodiazepine pada kasus-kasus forensik, terdapat beberapa tahapan uji yang penting dilakukan untuk membuktikan apakah korban benar telah melakukan penyalahgunaan, diantaranya yaitu uji skrining, uji

I Putu Purba Teguh Grantica, Made Dewi Widyastuti, Anak Agung Gde Jaya Santika, Ni Putu Ayu Kristiara Dewi Program Studi Farmasi, Fakultas Matematika dan Ilmu Pengetahuan Alam, Universitas Udayana 
konfirmasi, dan uji determinasi.

Salah satu teknik immunoassay, yaitu strip test merupakan salah satu metode untuk uji skrining yang telah digunakan secara umum dalam analisis suatu zat terlarang dalam sampel materi biologis. Teknik ini menggunakan antidrug - antibodi untuk mengidentifikasi obat dan metabolitnya yang terdapat di dalam sampel (materi biologis) [3]. Hasil uji skrining dapat dijadikan sebagai petunjuk dan dasar dugaan, tetapi belum dapat dijadikan suatu barang bukti yang kuat dalam pengadilan bahwa seseorang telah mengonsumsi zat terlarang [2]. Hal ini dikarenakan uji skrining belum mampu memberikan informasi mengenai jenis senyawa spesifik yang terkandung dalam sampel, sehingga perlu dilakukan uji konfirmasi untuk mengetahui jenis senyawa spesifik yang dianalisis dan uji determinasi untuk menentukan kadar dari senyawa yang terkonfirmasi tersebut.

Berdasarkan penelitian sebelumnya, sudah pernah dilakukan uji konfirmasi dan determinasi untuk senyawa golongan benzodiazepine dengan menggunakan metode HPLC DAD [4]. Metode HPLC ini memiliki kekurangan yaitu membutuhkan pelarut dengan grade HPLC yang banyak sehingga memerlukan biaya yang mahal [5]. Oleh karena itu perlu adanya pengembangan metode dengan hasil yang baik dan membutuhkan biaya yang lebih 3 murah. Salah satu metode yang dapat diterapkan yaitu KLTSpektrofotodensitometri.

KLT-Spektrofotodensitometri merupakan metode analisis yang didasarkan pada prinsip interaksi radiasi elektromagnetik (REM) dengan analit yang berupa bercak atau noda pada plat [6]. Metode KLTSpektrofotodensitometri memiliki kelebihan yaitu diantaranya pengerjaan relatif mudah dan cepat karena dapat digunakan untuk analisis beberapa senyawa dalam sekali running (simultan), memiliki spesifisitas yang cukup tinggi, biaya pengoperasian relatif murah, dan jumlah pelarut yang digunakan relatif sedikit [7]. Oleh karena itu, tujuan dari penelitian ini yaitu untuk melakukan pengembangan metode analisis dengan mengkombinasikan teknik immunoassay (strip test) dengan KLT-Spektrofotodensitometri dalam melakukan uji skrining, uji konfirmasi, dan uji determinasi senyawa golongan benzodiazepine dalam sampel urin.

\section{METODE PENELITIAN}

\section{Bahan dan Peralatan}

Alat-alat yang digunakan dalam penelitian ini yaitu satu set instrumen vortex, alat-alat gelas, Chamber, CAMAG TLC-Visualizer, CAMAG TLC-Scanner 4, neraca analitik, dan pipet kapiler.

I Putu Purba Teguh Grantica, Made Dewi Widyastuti, Anak Agung Gde Jaya Santika, Ni Putu Ayu Kristiara Dewi Program Studi Farmasi, Fakultas Matematika dan Ilmu Pengetahuan Alam, Universitas Udayana 
Serta bahan yang digunakan adalah sampel urin (Blind spike sample), tissue, pelarut diklorometana, flurazepam, isopropanol, amonimum hidroksida, aquadest, metanol, $\mathrm{NaC}_{2} \mathrm{H}_{2} \mathrm{O}_{3}$, $\mathrm{CH}_{3} \mathrm{COOH}, \mathrm{KH}_{2} \mathrm{PO}_{4}, \mathrm{NaOH}, \mathrm{HCl}$, $\mathrm{KH}_{2} \mathrm{PO}_{4}, \quad \mathrm{NaOH}$, diazepam, nordiazepam, etil asetat, Plat KLT Silika Gel $\mathrm{GF}_{254}$, amonia 25\%, toluene, aseton, etanol.

\section{Metode}

\section{Uji Skrining Golongan Senyawa} Benzodiazepine dalam Sampel Urin

Sampel spesimen urin yang digunakan yaitu urin yang diperoleh dari RS Bali Jimbaran, yang mana sampel urin dikumpulkan pada wadah yang bersih dan kering, diperhatikan adanya endapan. Urin yang mengandung endapan disentrifugasi dan disaring. Sampel urin yang telah siap dimasukkan secukupnya kedalam beaker glass. Disiapkan strip test untuk masing-masing senyawa. Strip test dicelupkan ke dalam sampel urin, ditunggu hingga urin bermigrasi, dijaga agar tidak melewati batas maksimum strip test. Diamkan strip test beberapa saat pada tempat datar yang tidak menyerap air. Lakukan pembacaan pada strip test

Hasil negatif ditunjukkan dengan dua strip, yaitu satu strip pada zona C dan satu strip pada zona T. Hasil negatif diakibatkan konsentrasi senyawa berada dibawah nilai cut-off. 4
Hasil positif ditunjukkan dengan munculnya strip pada zona C dan tidak munculnya strip pada zona $\mathrm{T}$. Hasil tidak valid apabila tidak munculnya strip pada zona $\mathrm{C}$.

\section{Uji Ekstraksi Benzodiazepine} Pembuatan Larutan Buffer Fosfat pH 6

Pembuatan buffer fosfat dilakukan dengan mengukur $\mathrm{KH}_{2} \mathrm{PO}_{4}$ sebanyak $0,05 \mathrm{~mL}$ dan memipet larutan $\mathrm{NaOH} 2 \mathrm{~N}$ sebanyak 0,0056 mL. Kemudian kedua larutan tersebut ditempatkan dalam labu ukur $5 \mathrm{~mL}$. Diad aquadest hingga tanda batas 5 $\mathrm{mL}$.

\section{Pembuatan Larutan Stok Konsentrasi 500 ppm}

Ditimbang standar senyawa golongan benzodiazepam, meliputi 7amino-flunitrazepam, diazepam, dan nordiazepam. Ditimbang $5 \mathrm{mg}$ masing-masing senyawa, dilarutkan dengan aquadest dalam beaker glass hingga larut. Larutan di tempatkan dalam labu ukur $10 \mathrm{~mL}$, lalu ditambahkan dengan aquadest hingga tanda batas $10 \mathrm{~mL}$.

\section{Pembuatan Larutan Baku 10 ppm}

Dipipet $0,2 \mathrm{~mL}$ larutan stok masing-masing senyawa, diantaranya adalah stok 7-amino flurazepam, diazepam dan nordiazepam ke dalam labu ukur $10 \mathrm{~mL}$. Diad dengan aquadest hingga tanda batas.

I Putu Purba Teguh Grantica, Made Dewi Widyastuti, Anak Agung Gde Jaya Santika, Ni Putu Ayu Kristiara Dewi Program Studi Farmasi, Fakultas Matematika dan Ilmu Pengetahuan Alam, Universitas Udayana 
Dimasukkan kedalam vial dan diberi label.

\section{Pembuatan Sampel Spike Placebo}

Dipipet $0,125 \mathrm{~mL}$ larutan baku 10 ppm dari senyawa 7-aminoflurazepam, diazepam, dan nordiazepam. Dimasukkan ke dalam labu ukur $5 \mathrm{~mL}$, diad dengan urin hingga tanda batas. Digojog hingga homogen, dimasukkan kedalam botol vial dan diberikan label.

\section{Ekstraksi Sampel dengan Metode Liquid-liquid Extraction (LLE)}

Sampel urin spike placebo sebanyak $1 \mathrm{~mL}$ dimasukkan kedalam labu vortex, ditambahkan dengan 100 $\mu$ Lbuffer fosfat $\mathrm{pH}$ 6. Kedalam sampel ditambahkan dengan $0,5 \mathrm{~mL}$ etil asetat. Larutan kemudian divortex selama 15 menit. Setelah kedua fase memisah, diambil fase etil asetat (fase etil asetat 1), ditampung dalam vial dan diberikan label. Fase air yang diperoleh ditambahkan dengan 100 $\mu \mathrm{L} \quad \mathrm{NaOH} \quad 1 \quad \mathrm{M}$, kemudian ditambahkan dengan etil asetat sebanyak $0,5 \mathrm{~mL}$. Dilakukan vortex kembali selama 15 menit. Fase organik yang diperoleh kemudian dimasukkan kedalam botol vial dan diberi label (fase etil asetat 2).

\section{Uji Konfirmasi Benzodiazepine dalam Sampel Urin Preparasi Fase Diam}

Disiapkan fase diam berupa plat silika gel $\mathrm{GF}_{254}$ untuk sistem TA 5 dengan masing-masing ukuran $10 \mathrm{x}$ $10 \mathrm{~cm}$, sedangkan untuk sistem TE yaitu dengan fase diam silika gel yang diimpregnasi dengan $0,1 \mathrm{M} \mathrm{KOH}$ dalam metanol dan dikeringkan.

\section{Pembuatan Larutan Stok Senyawa Standar}

Masing-masing senyawa (Morfin, Kafein, Papaverin $\mathrm{HCl}$, Kodein, Bromheksin, Teofilin, Dekstrometorfan) ditimbang $10 \mathrm{mg}$ dan ditempatkan dalam labu ukur 10 $\mathrm{mL}$. Diad metanol secukupnya sampai larut lalu ditambahkan hingga tanda batas.

\section{Pembuatan Larutan Pengoreksi hRf (100 ng/ $\mu \mathrm{L})$}

a) Larutan Pengoreksi hRf sistem TA:

Dibuat larutan pengoreksi $\mathrm{hRf}$ sistem TA dengan memipet stok larutan standar MDMA, Nitrazepam, Morfin HCl, Codein Fosfat, Trimetoprim, Flurazepam, Bromazepam, Teofilin, Papaverin $\mathrm{HCl}$, Clordiazepoxid, Diazepam, Efedrin $\mathrm{HCl}$, Bisacodyl sebanyak 0,5 $\mathrm{mL}$ dan diad dengan metanol pada labu ukur $5 \mathrm{~mL}$.

b) Larutan Pengoreksi hRf sistem TE:

Dibuat larutan pengoreksi hRf sistem TE dengan memipet stok larutan standar MDMA, Nitrazepam, Morfin $\mathrm{HCl}$, Codein Fosfat, Trimetoprim, Flurazepam, Bromazepam, Teofilin, Papaverin

I Putu Purba Teguh Grantica, Made Dewi Widyastuti, Anak Agung Gde Jaya Santika, Ni Putu Ayи Kristiara Dewi Program Studi Farmasi, Fakultas Matematika dan Ilmu Pengetahuan Alam, Universitas Udayana 
$\mathrm{HCl}$, Clordiazepoxid, Diazepam, Barbital, Phenobarbital, Allobarbital sebanyak $0,5 \mathrm{~mL}$ dan diad dengan metanol pada labu ukur $5 \mathrm{~mL}$.

\section{Pembuatan Fase Gerak}

a) Prosedur Fase Gerak Sistem TA: Dipipet 9,85 $\mathrm{mL}$ Metanol dan 0,15 mL Amonia pekat, kemudian ditempatkan dalam labu ukur $10 \mathrm{~mL}$. Digojog hingga homogen.

b) Prosedur Fase Gerak Sistem TE: Dipipet 4,36 mL Etil asetat, 5,39 $\mathrm{mL}$ Metanol, dan 0,26 mL Amonia $25 \%$ kemudian ditempatkan dalam labu ukur $10 \mathrm{~mL}$.

\section{Pembuatan KOH 0,1 M}

Ditimbang $\mathrm{KOH}$ sebanyak 0,28 gram. Kemudian dimasukkan ke dalam beaker glass. Lalu dilarutkan dengan aquadest secukupnya. Diaduk hingga $\mathrm{KOH}$ larut semua. Ditempatkan larutan tersebut ke dalam labu ukur volume $50 \mathrm{~mL}$, Diad aquadest sampai tanda batas. Digojog hingga homogen.

\section{Analisis dengan Metode KLT- Spektrofotodensitometri}

Proses pemisahan dilakukan dalam 2 chamber untuk 2 sistem fase gerak. Chamber 1 dijenuhkan dengan fase gerak sistem TA dan chamber 2 dijenuhkan dengan fase gerak sistem TE. Sampel hasil ekstraksi cair-cair dan senyawa standar ditotolkan pada kedua plat KLT sebanyak $10 \mu \mathrm{L}$. Kemudian masing-masing plat KLT 6 dielusi dalam chamber yang telah dijenuhkan dengan masing-masing fase gerak. Setelah dilakukan elusi hingga batas atas, plat KLT dianginanginkan hingga kering. Dideteksi dengan TLC-Visualizer pada sinar UV $254 \mathrm{~nm}$, sinar putih, dan sinar UV $366 \mathrm{~nm}$. Dilakukan pencocokan spektrum sampel pada library pada aplikasi WinCats. Kemudian dihitung harga hRf dan hRfc dari masingmasing senyawa.

\section{Uji Determinasi Benzodiazepine dari Sampel Urin Preparasi Fase Diam}

Disiapkan fase diam berupa plat silika gel $\mathrm{GF}_{254}$ dengan ukuran $20 \mathrm{x}$ $10 \mathrm{~cm}$.

\section{Penyiapan Fase Gerak Sistem TE}

Dipipet 21,25 mL Etil asetat, 2,5 $\mathrm{mL}$ Metanol, dan 1,25 mL Amonia $25 \%$ kemudian ditempatkan dalam labu ukur $25 \mathrm{~mL}$. Digojog hingga homogen.

\section{Pembuatan Larutan Standar Flurazepam 5 mg/mL}

Ditimbang sebanyak $50 \mathrm{mg}$ standar Flurazepam, ditempatkan ke dalam beaker glass. Serbuk dilarutkan dengan metanol, dimasukkan ke dalam labu ukur $10 \mathrm{~mL}$, diad dengan metanol hingga tanda batas $10 \mathrm{~mL}$.

$\begin{array}{lcr}\text { Pembuatan } & \text { larutan } & \text { Seri } \\ \text { Flurazepam } & \text { Konsentrasi } & 200 \\ \mu \mathrm{g} / \mu \mathrm{L} ; \quad 500 & \mu \mathrm{g} / \mu \mathrm{L} ; 1000 & \mu \mathrm{g} / \mu \mathrm{L} ;\end{array}$


$1500 \mu \mathrm{g} / \mu \mathrm{L} ; 2000 \mu \mathrm{g} / \mu \mathrm{L} ; 2500$ $\mu \mathrm{g} / \mu \mathrm{L}$.

Pembuatan Larutan Seri Flurazepam dilakukan dengan melakukan pemipetan larutan stok Flurazepam $5000 \quad \mu \mathrm{g} / \mathrm{mL}$ masingmasing $0,2 \mathrm{~mL} ; 0,5 \mathrm{~mL} ; 1 \mathrm{~mL} ; 1,5$ $\mathrm{mL} ; 2 \mathrm{~mL}$, dan 2,5 mL. Masingmasing dimasukkan ke dalam labu ukur $5 \mathrm{~mL}$. Ditambahkan metanol hingga tanda batas. Digojog hingga homogen dan dipindahkan ke dalam botol vial.

\section{Analisis dengan Metode KLT- Spektrofotodensitometri}

Ditotolkan masing - masing larutan seri dan sampel sebanyak 10 $\mu \mathrm{L}$ pada plat KLT sehingga diperoleh konsentrasi larutan seri dalam totolan yakni 1000-10.000 ng/spot. Setelah semua seri dan sampel ditotolkan dan dielusi, dideteksi pada TLCVisualizer pada sinar UV $254 \mathrm{~nm}$, sinar putih, dan sinar UV $366 \mathrm{~nm}$, kemudian dideteksi kembali pada panjang gelombang maksimum flurazepam yang diperoleh.

\section{HASIL DAN PEMBAHASAN}

Dewasa ini penyalahgunaan obatobatan narkotika dan psikotropika marak terjadi di masyarakat Indonesia. Hal ini tidak saja menjadi masalah hukum namun akan menjadi masalah pada bidang kesehatan. Oleh karena itu, diperlukan keterlibatan ahli forensik dalam menanggulangi peredaran senyawa narkotik dan 7 psikotropika di masyarakat. Pada analisis toksikologi forensik, pada umumnya target analisis (racun) tidak diketahui dengan pasti sebelum dilakukan analisis. Oleh karena itu, dilakukan uji skrining atau uji penapisan untuk mengetahui golongan senyawa yang terkandung dalam sampel yang dianalisis.

Uji skrining terhadap sampel biologis berupa urin yang diduga mengandung senyawa narkotika dan psikotropika yang mana uji skrining dilakukan untuk mengetahui golongan senyawa yang terdapat pada sampel urin. Hasil uji skrining dapat dijadikan sebagai petunjuk dan dasar dugaan, tetapi belum dapat dijadikan suatu barang bukti yang kuat dalam pengadilan bahwa seseorang telah mengonsumsi zat terlarang. Hal ini dikarenakan uji skrining belum mampu mendeteksi atau menunjukkan jenis senyawa spesifik yang terkandung dalam sampel [3].

Sebelum melakukan uji skrining, terlebih dahulu dilakukan tahap persiapan sampel yang meliputi pemerikaan organoleptis pada sampel urine yang mana dari volume total urin diambil $5 \mathrm{~mL}$ urine untuk diamati. Secara organoleptis sampel urin yang dianalisis berwarna kuning agak keruh dan berbau normal tidak tercium bau obat-obatan. $\mathrm{pH}$ sampel diukur menggunakan indikator $\mathrm{pH}$ universal dan diperoleh $\mathrm{pH}$ urine sebesar 6. Hal ini menunjukkan bahwa $\mathrm{pH}$ urine yang dianalisis 
termasuk $\mathrm{pH}$ urine normal sehingga uji skrining dapat dilanjutkan. Nilai $\mathrm{pH}$ urine normal adalah 4,4-8,0 [8].

Uji skrining pada kesempatan ini dilakukan dengan metode immunoassay menggunakan strip test yang spesifik dengan senyawa golongan amfetamin, benzodiazepine, barbiturate, dan opiat. Mekanisme kerja dari strip test adalah bedasarkan ikatan antigen antibodi. Prinsip dari strip test yaitu apabila IgG antinarkoba-substrat telah jenuh oleh narkoba sampel, maka IgG antinarkoba-substrat tidak akan berikatan dengan narkoba-enzimnya, sehingga tidak terjadi reaksi enzim-substrat yang menghasilkan warna (sampel positif narkoba), dan begitu pula sebaiknya, jika IgG anti-narkobasubstrat berikatan dengan narkobaenzimnya secara menyeluruh atau sebagian, maka akan terjadi reaksi enzim-substrat yang berwarna penuh (gelap) atau lamat-lamat (ragu-ragu). [9].

Hasil uji skrining yang dilakukan pada penelitian ini menunjukkan hasil bahwa strip test untuk golongan benzodiazepine menunjukkan hasil positif yaitu terdapat hanya terdapat 1 strip berwarna merah pada zona $\mathrm{C}$ pada strip test. Namun, hasil dari pemeriksaan strip test ini masih mungkin merupakan hasil positif ataupun negatif palsu. Hasil positif palsu dapat disebabkan oleh adanya reaksi silang (cross reaction) [3]. Reaksi silang dapat timbul karena 8 enzim enzim dalam alat uji skrining terkadang membentuk ikatan tidak spesifik dengan suatu zat/obat akibat adanya kemiripan struktur zat/obat tersebut dengan golongan narkotika dan psikotropika yang akan diuji. Dimana reaksi silang yang mungkin terjadi dengan golongan benzodiazepine adalah oxaprozin dan setraline (zoloft) [2]. Sedangkan, hasil negatif palsu dapat disebabkan karena kadar senyawa narkoba pada urine lebih rendah dari nilai cut off dari strip test yang digunakan [10].

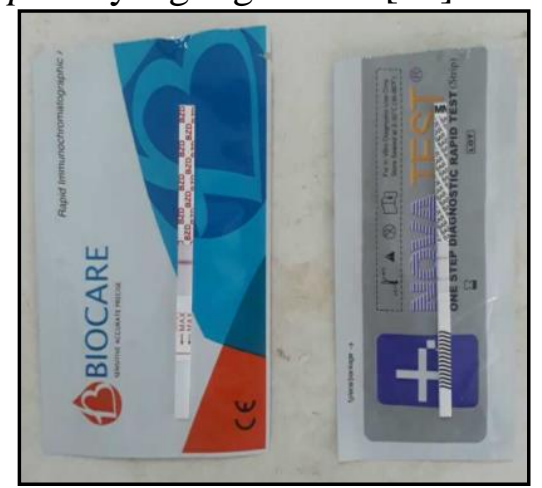

Gambar 1. Hasil Pengamatan

Sampel Menggunakan Strip Test Positif Benzodiazepine dan Strip Test Negatif Barbiturat

Tahap analisis selanjutnya adalah tahap ekstraksi sampel dengan menggunakan metode LLE. Ekstraksi cair-cair (LLE) merupakan suatu cara ekstraksi yang bertujuan untuk preparasi sampel untuk memisahkan analit dari komponen-komponen pengotor yang mungkin mengganggu saat dilakukan deteksi maupun kuantifikasi analit. LLE dapat 
dikatakan pula dengan proses ekstraksi yang memanfaatkan perbedaan kelarutan zat yang akan dipisahkan diantara dua atau lebih pelarut yang memiliki polaritas yang berbeda. Prinsip dari LLE yaitu melarutkan secara sempurna target analit dan hanya sedikit melarutkan atau bahkan memisahkan senyawa lain (pengotor) yang akan mengganggu analisis lebih lanjut [5]. Di samping itu, ekstraksi pelarut juga berfungsi untuk memekatkan analit yang ada dalam sampel dengan jumlah kecil sehingga mempermudah dalam deteksi atau kuantifikasi analit [11]. Pertimbangan pemilihan pelarut pengekstraksi adalah sifat fisiko kimia terutama kelarutan dari senyawa-senyawa yang diduga terdapat dalam sampel. Kelarutan senyawa derivat benzodiazepine seperti diazepam yaitu sedikit larut dalam air, larut dalam 25 bagian etanol, dalam 2 bagian kloroform dan 39 bagian eter. Memiliki pKa 3,5; 3,3 [12].

Fraksi yang diambil dari proses ekstraksi cair-cair terhadap sampel adalah fraksi organik. Hal ini didasarkan oleh perhitungan jumlah senyawa yang terion dan takterion yang diperoleh dari perhitungan menggunakan persamaan dari Hukum Handelson-Hasselbach. Perhitungan dilakukan terhadap senyawa yang paling banyak penggunaannya di Indonesia diantaranya yaitu diazepam (valium), nitrazepam (mogadon), 9 flurazepam dan bromazepam, penentuan juga dilakukan terhadap metabolit aktif dari diazepam dalam urin, yaitu dismetildiazepam, oxazepam dan tenazepam. ${ }^{[1]}$ Benzodiazepine merupakan senyawa yang memiliki pKa dengan rentang dari asam hingga basa $(3,5-11,6)$. Berdasarkan penentuan ini, digunakan kondisi ekstraksi dengan pH 6 untuk menjamin senyawa benzodiazepine dalam sampel dapat terekstraksi seluruhnya. $\mathrm{pH}$ tersebut dapat menjamin bahwa senyawa golongan benzodiazepine yang terdapat dalam sampel tetap berada pada bentuk tak terionnya, sehingga memiliki kelarutan cenderung ke pelarut organik. Buffer fosfat $\mathrm{pH} 6$ digunakan untuk menjamin kondisi pelarut yang digunakan untuk ekstraksi tetap memiliki $\mathrm{pH} \pm 6$. Pelarut organik yang digunakan untuk ekstraksi adalah etil asetat. Tujuan dibawanya analit kedalam pelarut organik adalah untuk mempermudah proses preparasi sampel setelah ekstraksi, yaitu pada proses penguapan. Etil asetat memiliki titik didih $77,1^{\circ} \mathrm{C}$, sedangkan aquadest sebagai fase air memiliki titik didih $100^{\circ} \mathrm{C}$ [13]. Hal tersebut mengakibatkan lebih mudahnya fase organik menguap dibandingkan dengan fase air dan mengakibatkan waktu serta suhu pemanasan yang digunakan lebih rendah, sehingga mampu memperkecil peluang kehilangan analit yang diakibatkan oleh

I Putu Purba Teguh Grantica, Made Dewi Widyastuti, Anak Agung Gde Jaya Santika, Ni Putu Ayu Kristiara Dewi Program Studi Farmasi, Fakultas Matematika dan Ilmu Pengetahuan Alam, Universitas Udayana 
pemanasan berlebih. Hasil yang diperoleh berupa fase air untuk ketiga replikasi diperoleh sebanyak $2 \mathrm{~mL}$ dan fase organik untuk ketiga replikasi diperoleh sebanyak $1 \mathrm{~mL}$.

Uji konfirmasi dilakukan dengan menggunakan metode KLTSpektrofotodensitometri. Penggunaan KLT-Spektrofotodensitometri dapat menganalisis kualitatif dengan membandingkan parameter nilai Rf. Dua senyawa dapat dikatakan identik apabila memiliki nilai $\mathrm{Rf}$ yang sama bila diukur pada kondisi analisis yang sama. Selain itu, analisis kualitatif dengan metode ini juga dapat memanfaatan spektrum pada Library Street Drugs dari Camag sebagai uji konfirmasi yaitu dengan membandingkan spektrum analit sampel dengan spektrum pustaka. Adanya perubahan terhadap nilai Rf yang dapat disebabkan oleh faktor lingkungan ataupun fase diam yang digunakan, maka analisis kualitatif dilakukan dengan memanfaatkan nilai hRf terkoreksi (hRfc). Keuntungan hRfc dibandingkan dengan harga hRf adalah nilai hRfc lebih konsisten dengan variasi faktor-faktor lingkungannya, sehingga dapat digunakan sebagai data yang lebih akurat dari senyawa yang dianalisis.

Analisis dilakukan dengan menggunakan 2 fase gerak, diantaranya adalah sistem TE dan sistem TA. Konfirmasi senyawa dilakukan dengan menggunakan dua sistem, hal ini dilakukan untuk 10 meminimalisir kesalahan hasil konfirmasi yang mungkin terjadi. Nilai yang digunakan untuk konfirmasi senyawa uji adalah perbandingan antara nilai $\mathrm{hRfc}$ standar dan hRf analit. Faktor-faktor yang dapat mempengaruhi harga $\mathrm{hRf}$ adalah struktur kimia senyawa yang dipisahkan (pengaruh $\mathrm{pH}$ atau tidak), sifat penyerapan, ketebalan dan kerapatan lapisan penyerap (adsorben), teknik pemisahan, pelarut (fase gerak), derajat kejenuhan, suhu dan jumlah cuplikan [14]. Oleh karena itu, keterampilan seorang analis dan kondisi lingkungan sangat berpengaruh terhadap hasil yang diperoleh.

Tabel 1. Hasil Uji Konfirmasi dengan Sistem TE

\begin{tabular}{ccc}
\hline Track & hRf & hRfc \\
\hline Teofilin & 16 & 11 \\
Morfin & 24 & 20 \\
Kodein & 36 & 35 \\
Trimetrofin & 43 & 45 \\
Papaverin & 68 & 69 \\
HCl & & \\
\hline Sampel LLE & 65 & $55,12-$ \\
& & 77,12 \\
\hline
\end{tabular}

Hasil konfirmasi terhadap senyawa yang terdapat dalam sampel pada sistem TE meliputi flurazepam $(\mathrm{hRfc}=71)$, nitrazepam $(\mathrm{hRfc}=64)$, bromazepam $(\mathrm{hRfc}=63)$ dan diazepam $(\mathrm{hRfc}=76)$ dikarenakan keseluruhan nilai hRfc dari senyawa tersebut memasuki rentang hRfc

I Putu Purba Teguh Grantica, Made Dewi Widyastuti, Anak Agung Gde Jaya Santika, Ni Putu Ayu Kristiara Dewi Program Studi Farmasi, Fakultas Matematika dan Ilmu Pengetahuan Alam, Universitas Udayana 
senyawa dengan error window sistem TE yaitu 11 sehingga diperoleh hasil seperti pada Tabel 1. Hasil dikonfirmasi dengan membandingkan spektrum yang diperoleh dari sampel dengan spektrum standar dari masingmasing senyawa yang digunakan dalam sistem TE. Hasil overlapping spektrum ini menunjukkan bahwa spektrum yang paling mendekati spektrum analit dalam sampel ada flurazepam dengan nilai korelasi yang diperoleh lebih besar dari 0,9

(Gambar 2).

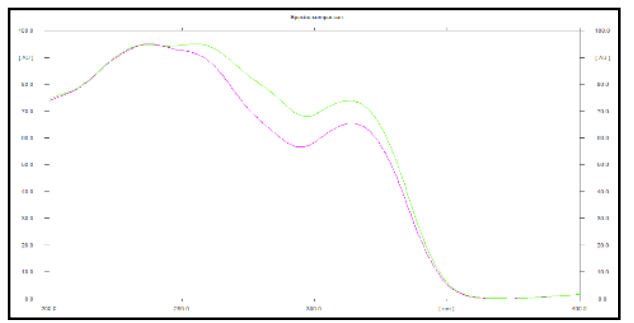

Gambar 2. Spektrum Flurazepam (ungu) dengan Sampel (hijau) pada Sistem TE

Tabel 2. Hasil Uji Konfirmasi dengan Sistem TA, Error Window $=9$

\begin{tabular}{ccc}
\hline Track & hRf & hRfc \\
\hline Efedrin & 37 & 30 \\
Codein fostat & 42 & 33 \\
Morfin & 42 & 37 \\
Trimetoprim & 66 & 55 \\
Bisacodyl & 76 & 74 \\
\hline Sampel LLE & 67 & $47,9-$ \\
& & 65,9 \\
\hline
\end{tabular}

11
Hasil yang diperoleh dari penentuan dengan sistem TA dengan error window 9 adalah rentang hRfc analit seperti yang terdapat pada Tabel 2. Nilai hRfc dari senyawa yang masuk kedalam rentang ini adalah flurazepam ( $\mathrm{hRfc}=62)$, clordiazepoxide $(\mathrm{hRfc}=62)$, dan bromazepam $(\mathrm{hRfc}=61)$. Penentuan dilakukan dengan melaukan overlaping spektrum antara senyawa standar dengan analit pada sistem TA. Hasil yang diperoleh menunjukkan analit merupakan flurazepam dengan nilai korelasi spektrum diatas 0,9.

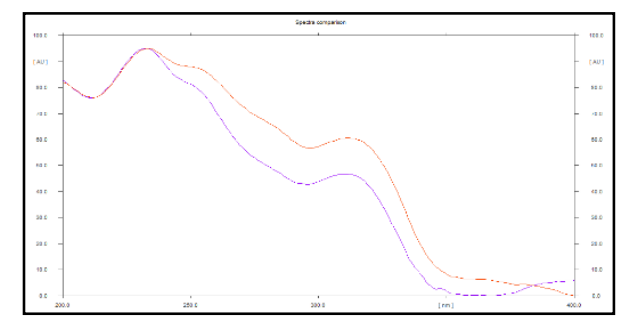

Gambar 3. Spektrum Flurazepam (ungu) dengan Sampel (merah) pada sistem TA

Berdasarkan hasil uji konfirmasi dengan penentuan nilai hRfc pada 2 sistem fase gerak dan overlapping spektrum diketahui bahwa senyawa yang terdapat pada sampel adalah senyawa flurazepam. Hasil ini kemudian dijadikan acuan sebagai analisis untuk uji konfirmasi, sebagai penentuan kadar analit yang terdapat dalam sampel.

Metode uji determinasi yang digunakan adalah metode KLTSpektrofotodensitometri dengan menggunakan sistem TE. Sistem TE

I Putu Purba Teguh Grantica, Made Dewi Widyastuti, Anak Agung Gde Jaya Santika, Ni Putu Ayu Kristiara Dewi Program Studi Farmasi, Fakultas Matematika dan Ilmu Pengetahuan Alam, Universitas Udayana 
dipilih karena menghasilkan pemisahan yang baik dan peak yang dihasilkan paling baik dibandingkan sistem TA. Sehingga pada uji determinasi ini digunakan sistem TE yang diharapkan mampu menetapkan kadar flurazepam dengan akurat.

Pada tahap determinasi, digunakan larutan seri dengan rentang
400 ng - 5000 ng. Pemilihan konsentrasi larutan seri didasarkan atas perbandingan AUC dari standar sampel LLE yang ditotolkan pada uji konfirmasi yang dapat dilihat pada Tabel 3.

Tabel 3. Hasil AUC Determinasi Flurazepam

\begin{tabular}{ccccc}
\hline Senyawa & $\begin{array}{c}\text { Kons. larutan } \\
(\mathbf{n g} / \boldsymbol{\mu L})\end{array}$ & Totolan & $\begin{array}{c}\text { Kons. } \\
\text { totolan }(\mathbf{n g})\end{array}$ & AUC \\
\hline Seri 1 & 200 & $2 \mu \mathrm{L}$ & 400 & 3877,5 \\
Seri 2 & 500 & $2 \mu \mathrm{L}$ & 1000 & 8115,2 \\
Seri 3 & 1000 & $2 \mu \mathrm{L}$ & 2000 & 12869,9 \\
Seri 4 & 1500 & $2 \mu \mathrm{L}$ & 3000 & 16593,2 \\
Seri 5 & 2000 & $2 \mu \mathrm{L}$ & 4000 & 18766,9 \\
Seri 6 & 2500 & $2 \mu \mathrm{L}$ & 5000 & 23696,6 \\
Sampel I & - & $3 \mu \mathrm{L}$ & - & 7102,1 \\
Sampel II & - & $3 \mu \mathrm{L}$ & - & 6957,3 \\
Sampel III & - & $3 \mu \mathrm{L}$ & - & 6808,7
\end{tabular}

\section{Kurva Kalibrasi}

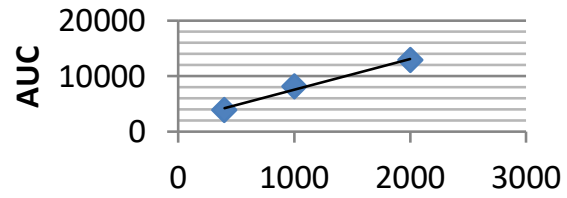

$y=5.5319 x+2018$ Konsentrasi (ng)

$R^{2}=0.9879$

Gambar 4. Kurva Kalibrasi Regresi

Linier Flurazepam
Berdasarkan dari kurva kalibrasi pada Gambar 5, dapat ditentukan nilai LOD dan LOQ (batas deteksi dan batas kuantifikasi) dari determinasi flurazepam. Hasil yang diperoleh LOD sebesar 379,395 ng dan LOQ sebesar 1264,642 ng. Setelah itu, dilakukan penetapan kadar flurazepam dalam sampel LLE. Kurva kalibarasi (Gambar 5) yang diperoleh juga digunakan untuk

12

I Putu Purba Teguh Grantica, Made Dewi Widyastuti, Anak Agung Gde Jaya Santika, Ni Putu Ayu Kristiara Dewi Program Studi Farmasi, Fakultas Matematika dan Ilmu Pengetahuan Alam, Universitas Udayana 
menentukan kadar analit yang terdapat dalam sampel LLE urin. Hasil penetapan kadar dapat dilihat pada Tabel 4.

Tabel 4. Hasil Penetapan Kadar Flurazepam

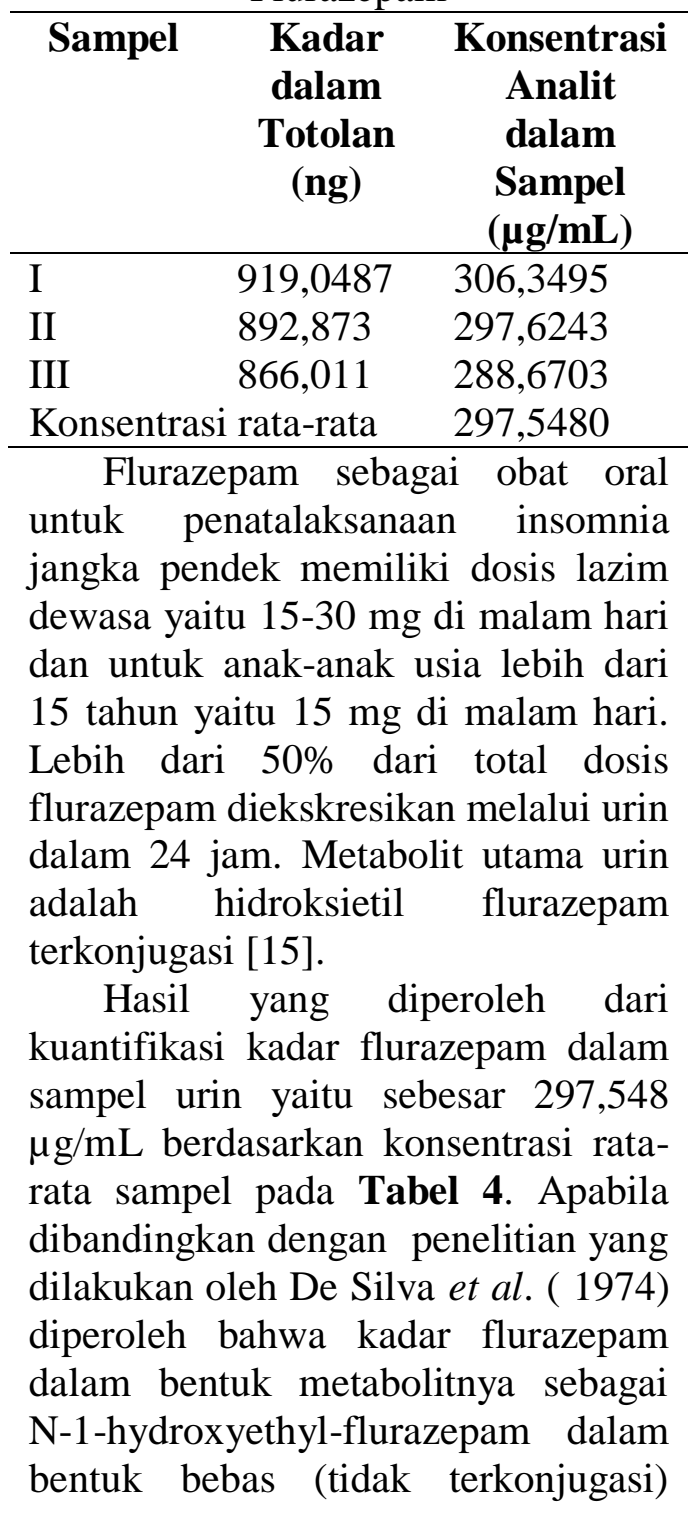

dalam sampel urin manusia yang telah diberikan flurazepam (Dalmane ${ }^{\circledR}$ ) sebelumnya yaitu sebesar 29,7 $\mu \mathrm{g} / \mathrm{mL}$, yang mana masih berada di bawah dosis letal dari flurazepam yaitu sebesar 50-200 $\mu \mathrm{g} / \mathrm{mL}$ [16]. Sedangkan hasil penelitian ini menunjukkan bahwa kadar flurazepam yang diperoleh yaitu sebesar 297,548 $\mu \mathrm{g} / \mathrm{mL}$ yang mana berada jauh di atas dosis letal dari flurazepam sehingga diduga sampel urin yang digunakan yaitu urin dari pasien overdosis flurazepam yang penggunaannya dapat diketahui sebagai penyalahgunaan flurazepam yang bahkan dapat menimbulkan kematian karena kadar flurazepam yang ditemukan dalam sampel urin jauh di atas dosis letal flurazepam.

Penyalahgunaan dengan cara mengonsumsi golongan benzodiazepin seperti flurazepam telah diatur dalam UU RI No. 5 Tahun 1997 tentang Psikotropika. Sesuai dengan perubahan Permenkes RI No. 3 Tahun 2017 tentang Perubahan Penggolongan Psikotropika, Flurazepam digolongkan ke dalam Psikotropika Golongan IV, yang mana psikotropika Golongan IV yaitu golongan psikotropika yang lazim digunakan dalam terapi yang memiliki potensi ringan mengakibatkan ketergantungan. Flurazepam dalam pengobatan harus diperoleh dari resep dokter dan penggunaannya harus selalu dibawah pengawasan tenaga 
kesehatan. Penyalahgunaan obat golongan psikotropika dapat mengakibatkan ketergantungan apabila dalam penggunaannya tidak berada dalam pengawasan tenaga kesehatan yang mempunyai keahlian. Pada pasal 62 UU RI No. 5 Tahun 1997 disebutkan bahwa seseorang yang memiliki atau membawa psikotropika secara ilegal dapat dipidana penjara paling lama lima tahun dan pidana denda paling banyak seratus juta rupiah. Selain itu, pada pasal 37 disebutkan bahwa bagi penyalah guna psikotropika tersebut wajib menjalani rehabilitasi medis dan rehabilitasi sosial [17].

\section{KESIMPULAN}

Uji skrining yang dilakukan adalah menggunakan strip test. Dimana hasil positif yang diperoleh adalah pada sampel urin positif mengandung senyawa golongan Benzodiazepin. Berdasarkan perhitungan hRfc standar yang digunakan untuk masing-masing sistem fase gerak diperoleh bahwa uji konfirmasi dengan nilai $\mathrm{hRfc}$ pada dua sistem fase gerak yakni TE dan TA terkonfirmasi senyawa golongan Benzodiazepine yakni Flurazepam pada kedua sistem tersebut, yang mana tingkat korelasi (kemiripan) dari spektrum sampel dan standar Flurazepam yang paling tinggi dengan nilai lebih besar dari 0,9. Analit yang diperoleh adalah 14 flurazepam dengan kadar 297,5480 $\mu \mathrm{g} / \mathrm{mL}$ berada jauh di atas dosis letal flurazepam yaitu $50-200 \mu \mathrm{g} / \mathrm{mL}$, sehingga penggunaannya dapat diketahui sebagai penyalahgunaan flurazepam yang bahkan dapat menimbulkan kematian karena kadar flurazepam yang ditemukan dalam sampel urin jauh di atas dosis letal flurazepam.

\section{DAFTAR PUSTAKA}

[1] Katzung BG. Basic \& clinical pharmacology. 10th ed. New York: McGraw-Hill Companies; 2006.

[2] Badan Narkotika Nasional. Pedoman pemeriksaan laboratorium narkotika, psikotropika dan obat berbahaya. Jakarta: Badan Narkotika Nasional; 2008.

[3] Wirasuta, IMAG. Analisis toksikologi forensik dan interpretasi temuan analisis. Indonesian Journal of Legal and Forensic Sciences. 2008; 1 (1): 47-55.

[4] Ali KT, Susanti NMP, Wirasuta IMAG. Validasi metode uji konfirmasi senyawa golongan benzodiazepin dengan HPLCDAD. Jurnal Farmasi Udayana. 2013; 2 (1): 1-16.

[5] Gandjar IG dan Rohman A. Kimia farmasi analisis. Yogyakarta: Pustaka Pelajar; 2016. 
[6] Rohman A. Kromatografi untuk analisis obat. Yogyakarta: Graha Ilmu; 2009.

[7] Wulandari L., Retnaningtyas Y., dan Mustafidah D. Pengembangan dan validasi metode kromatografi lapis tipis densitometri untuk penetapan kadar teofilin dan efedrin hidroklorida secara simultan pada sediaan tablet. JKTI. 2013; 15 (1): 15-21.

[8] Shaafie IA, Sreedharan J, Muttappalymyalil J, Freeg MAHA and Mathew E. Effect of urinary $\mathrm{pH}$ and specific gravity in urothialisis. Journal of Gulf Medical. 2012; 1:26-31.

[9] Suwarso. Manajemen laboratoris penyalahgunaan obat dan komplikasinya. Yogyakarta: Bagian Patologi Klinik Fakultas Kedokteran Universitas Gajah Mada; 2002.

[10] SAMHSA. Tobacco use cessation during substance abuse treatment counseling. 2004; 10 (2). [Dikutip 2019 September 15]. Tersedia pada: www.samhsa.gov

[11] Basset J. Buku ajar Vogel kimia analisis kuantitatif anorganik. Jakarta: Penerbit Buku Kedokteran EGC; 1994.

[12] Moffat AC, Osselton MD, and Widdop B. Clarke's analysis of drugs and poisons in pharmaceuticals, body fluids, and postmortem material. $4^{\text {th }}$ ed.
London: Pharmaceutical Press; 2011.

[13] Depkes RI. Farmakope Indonesia. $5^{\text {th }}$ ed. Jakarta: Departemen Kesehatan Republik Indonesia; 2014.

[14] Sastrohamidjojo H. Kromatografi. 2nd Ed. Yogyakarta: Liberty; 1991.

[15] Aderjan R. and Mattern R. Eine todlich verlaufene monointoxikation mit flurazepam (dalmadorm). probleme bei der toxicologischen beurteilung. Arch. Toxicol. 1979; 43: 69-75.

[16] De Silva JAF, Puglisi CV, Brooks MA, and Hackman MR. Determination of Flurazepam $\left(\right.$ Dalmane $^{\circledR}$ ) and Its Major Metabolites in Blood by Electron-Capture Gas-Liquid Chromatography and In Urine by Differential Pulse Polarography. Journal of Chromatography. 1974; 99: 461-483.

[17] Presiden RI. Undang-Undang Republik Indonesia Nomor 5 Tahun 1997 tentang Psikotropika. Jakarta: Presiden Republik Indonesia; 1997. 